\title{
Nanofertilizers for enhancing nutrient use efficiency, crop productivity and economic returns in winter season crops of Rajasthan
}

\author{
YOGENDRA KUMAR ${ }^{1}$, K.N. TIWARI ${ }^{1}$, TARUNENDU SINGH ${ }^{1}$, NAVEEN KUMAR SAIN ${ }^{1}$, SRI \\ LAXMI $^{1}$, RAMESH VERMA ${ }^{1}$, GIRISH CHANDRA SHARMA ${ }^{1}$ AND RAMESH RALIYA ${ }^{2}$ \\ ${ }^{1}$ IFFCO, IFFCO Sadan, C-1, District Centre, Saket Place, New Delhi, \\ ${ }^{2}$ IFFCO Nano Biotechnology Research Centre, Kalol, Gujarat
}

Received: August, 2020; Revised accepted: September, 2020

\begin{abstract}
The results of 600 on-farm trials with 8 crops conducted during winter season in different districts of Rajasthan have proved that the quantity of urea being applied by the farmers to supply nitrogen to the crops can be successfully reduced to half. The yields obtained with 50\% less nitrogen plus 2 sprays of nano-nitrogen in standing crops gave yields higher than that applied in most of the 8 crops tested in these trials. Apart from this, effect of the Nano-Zn and Nano-Cu was also evaluated. As the deficiencies of these micronutrients were not universal like nitrogen, the significant responses to these nanofertilizers depended on the magnitude of deficiency of specific micronutrients and the nature of the crops. These results clearly establish that with application of nanofertilizers, the nutrient use efficiency can be significantly enhanced as revealed by 50 per cent saving of urea through 2 sprays of Nano N.Nanofertilizers are considered as a novel approach towards saving of nutrients, in particular nitrogen, and protecting the environment. This paper describes the results of 600 on-farm trials conducted on 8 crops grown during winter season of 2019-20.
\end{abstract}

Keywords: Nanofertilizers, nutrient use efficiency, crop productivity, winter season crops

\section{INTRODUCTION}

World agricultural cropping systems are intensively using large amount of fertilizers, pesticides, herbicides to achieve more production per unit area per unit time but using more doses than optimum of these chemicals and fertilizers leads to several problems like environment pollution (soil, water, air pollution), low input use efficiency, decreased quality of food products, increasing problems of pests (weeds, diseases, insects), less income from the production, soil degradation, increasing incidence of multi-nutrient deficiencies in soil and plants, decreasing population of beneficial organisms in the soil and on the whole soil health problems. Despite these problems, there is also challenge to ensure food, nutrition and environment security to feed the growing population of the world in the face of shrinking natural resources and deteriorating soil health. Therefore, in the future, there is need to produce nutritive agricultural produce rich in protein and other essential nutrients required to the human and animal consumption that is why emphasis should be laid on production of high quality food with the required level of nutrients and proteins. Apparently, agriculture in the twenty-first century is facing manifold challenges for producing more food by addressing the problems of rapidly global population, unpredictable climate change, decreasing agricultural productivity, variable labour force, and increased growing urbanization. These problems seem to intensify ferociously by 2050 when the world have to feed the population of over 9 billion. Agriculture as a source of food, feed, fodder and fibre has always been increasingly important in a world of diminishing resources and with an everincreasing global population (Brennan 2012). There is also demanding need for agriculture to produce more output with less input. To address this scenario, the agriculture dependent countries have to adopt more advanced technologies, labour saving practices, and methods. The use efficiency of nutrients of traditional fertilizers is abysmally low. It has been reported that around $40-70 \%$ of nitrogen, 80 $90 \%$ of phosphorus, and $50-90 \%$ of potassium content of applied fertilizers are lost in the environment and could not reach the plant which causes significant economic losses (Trenkel 2010, Solanki et al. 2015).

Among most recent technical improvements in the field of agriculture, nanotechnology holds an eminent position in remodelling agriculture and food production to fulfil the demands in an efficient and cost- 
effective way. Nanotechnology is a promising tool and has the potential to foster a new era of precise farming techniques and therefore, may emerge as a possible solution for these problems. Nanotechnology has the potential to improve global food production and food quality (Sugunan and Dutta 2008). Engineered nanomaterials can alter agronomic traits including plant growth, biomass production; physiological parameters that directly influence yield and quality of produce (GardeaTorresdeyet al. 2014. Zheng et al. 2005).Nanofertilizers are nutrient carriers of nano dimensions ranging from 30 to $40 \mathrm{~nm}$ and capable of holding bountiful of nutrient ions due to their high surface area and release it slowly and steadily that commensurate with crop demand (Subramanian et al. 2015) and have a profound influence on crop production (Panwaret al. 2012, De Rosa et al. 2013). The use of nanofertilizers not only causes increased use efficiency through ultrahigh absorption of the nutrients, increase in photosynthesis caused by expansion in surface area of the leaves (INIC 2009) but also reduces the toxicity generated due to over application in the soil as well as reduces the split application of fertilizers (Naderi and Danesh-Shahraki 2013). Despite the high potential of NPS in enhancing plant growth and development, the information on the effect of nanofertilizers on agronomic traits based on field experiments are almost lacking. This research aims at studying the effect of IFFCO Nano fertilisers (Nano-N, Nano-Zn and Nano-Cu) on crop yield, nutrient use efficiency and economic returns.

\section{MATERIALS AND METHODS}

Six hundred on-farm trials were conducted with 8 crops namely wheat (Triticumaestivum), barley (Hordeum vulgare), maize (Zea mays), urdbean (Vigna mungo), chickpea (Cicer arietinum), mustard (Brassica juncea), isabgoal (Plantago ovata) and rose (Rosa damascene) in different districts of Rajasthan during winter season of 2019-20. The crops were sown in the month of November and December 2019 with 5 treatments (Table 1). The Nanofertilizers namely Nano-N, Nano-Zn and Nano-Cu (Picture 1) had nutrient concentrations of 25000, 5000 and 2000 ppm, respectively. Four $\mathrm{ml}$. of these liquid fertilisers were added in one litre of water and for one acre $500 \mathrm{ml}$ of nanofertilizers were added to 125 litres of water and sprayed as per treatments. The first spray was done 3 week after full germination in each crop and the second spray was made 10-15 days after first spray or 5 weeks after full germination. The fields were kept weed-free as far as practical according to means and will of the farmers. Plant protection measures were adopted as per need of the crop. The crops were harvested at full maturity and the yield data were recorded from the net plot area harvested.

\section{Table 1: Treatment details}

$$
\begin{array}{ll}
\mathrm{T}_{1} & \text { Farmer's Fertiliser Practice (FFP) } \\
\mathrm{T}_{2} & \text { FFP }-50 \% \mathrm{~N}+2 \text { Spray of Nano Nitrogen } \\
\mathrm{T}_{3} & \mathrm{FFP}+2 \text { Spray of Nano Zinc } \\
\mathrm{T}_{4} & \mathrm{FFP}+2 \text { Spray of Nano Cu } \\
\mathrm{T}_{5} & \text { FFP }-50 \% \mathrm{~N}+1 \text { Spray of Nano N }+1 \text { Spray of } \\
& \text { Nano } \mathrm{Zn}+1 \text { Spray of Nano Cu }
\end{array}
$$

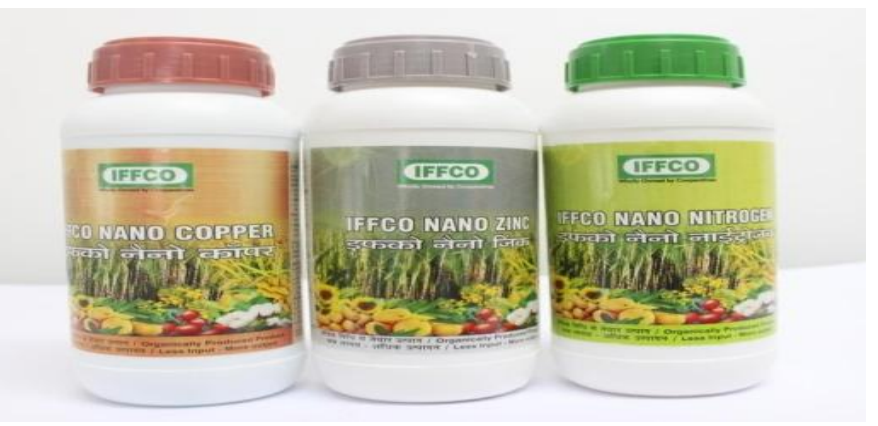

Picture 1: IFFCO Nanofertilizers tested in this investigation

\section{RESULTS AND DISCUSSION}

Data emanating from 600 on-farm trials with respect to economic yield, the range and mean of responses, additional yield and economic returns recorded over FFP for 8 crops are given in Table 2.The crop-wise results are being described in following paragraphs.

\section{Wheat (Triticum aestivum)}

Mean effects of nanofertilizers on grain yield of wheat under different treatments, additional yield and economic returns over FFP are summarized in Table 2 and Fig. 1. The lowest and highest grain yields as influenced by different nano- treatments varied between 2250 and 2400 and 6410 and $6875 \mathrm{~kg} \mathrm{ha}^{-1}$ respectively, the mean yields being in the range of 4330 to $4628 \mathrm{~kg} \mathrm{ha}^{-1}$. 
Table 2: Effect of nanofertilizers on yield of crops

\begin{tabular}{|c|c|c|c|c|c|c|}
\hline $\begin{array}{l}\text { Crop (Data in } \\
\text { parenthesis } \\
\text { are number } \\
\text { of trials) } \\
\end{array}$ & Parameters & \begin{tabular}{c|} 
Farmer \\
Fertilizer \\
Practice \\
(FFP) \\
\end{tabular} & $\begin{array}{l}\text { FFP }-50 \% N \\
+2 \text { Spray of } \\
\text { Nano }-\mathrm{N}\end{array}$ & $\begin{array}{l}\text { FFP }+2 \\
\text { Spray of } \\
\text { Nano-Zn }\end{array}$ & $\begin{array}{c}\text { FFP+ } 2 \\
\text { Spray of } \\
\text { Nano Cu }\end{array}$ & $\begin{array}{c}\text { FFP }(-50 \% N)+1 \\
\text { Spray of Nano-N+1 } \\
\text { Spray of Nano- } Z n+1 \\
\text { Spray of Nano-Cu }\end{array}$ \\
\hline \multirow{6}{*}{ Wheat (480) } & Lowest yield $\left(\mathrm{kg} \mathrm{ha}^{-1}\right)$ & 2250 & 2400 & 2370 & 2370 & 2380 \\
\hline & Highest yield $\left(\mathrm{kg} \mathrm{ha}^{-1}\right)$ & 6410 & 6760 & 6610 & 6580 & 6875 \\
\hline & Mean yield $\left(\mathrm{kg} \mathrm{ha}^{-1}\right)$ & 4330 & 4580 & 4490 & 4475 & 4628 \\
\hline & Response over FFP $\left(\mathrm{kg} \mathrm{ha}^{-1}\right)$ & - & 250 & 160 & 145 & 297.5 \\
\hline & Per cent increase over FFP & - & 5.77 & 3.7 & 3.35 & 6.87 \\
\hline & Net return over FFP (Rs. ha ${ }^{-1}$ ) & - & 4812.50 & 3080.00 & 2791.25 & 5726.88 \\
\hline \multirow{6}{*}{ Barley (9) } & Lowest yield $\left(\mathrm{kg} \mathrm{ha}^{-1}\right)$ & 3200 & 3380 & 3300 & 3250 & 3350 \\
\hline & Highest yield $\left(\mathrm{kg} \mathrm{ha}^{-1}\right)$ & 5260 & 5620 & 5730 & 5790 & 5900 \\
\hline & Mean yield $\left(\mathrm{kg} \mathrm{ha}^{-1}\right)$ & 4230 & 4500 & 4515 & 4520 & 4625 \\
\hline & Response over FFP $\left(\mathrm{kg} \mathrm{ha}^{-1}\right)$ & - & 270 & 285 & 290 & 395 \\
\hline & Per cent increase over FFP & - & 6.38 & 6.74 & 6.86 & 9.34 \\
\hline & Net return over FFP (Rs. ha-1) & - & 4117.50 & 4346.25 & 4422.50 & 6023.75 \\
\hline \multirow{6}{*}{ Maize (4) } & Lowest yield $\left(\mathrm{kg} \mathrm{ha}^{-1}\right)$ & 4100 & 4300 & 4400 & 4100 & 4500 \\
\hline & Highest yield $\left(\mathrm{kg} \mathrm{ha}^{-1}\right)$ & 5500 & 6000 & 5700 & 5550 & 6000 \\
\hline & Mean yield $\left(\mathrm{kg} \mathrm{ha}^{-1}\right)$ & 4800 & 5150 & 5050 & 4825 & 5250 \\
\hline & Response over FFP $\left(\mathrm{kg} \mathrm{ha}^{-1}\right)$ & - & 350 & 250 & 25 & 450 \\
\hline & Per cent increase over FFP & - & 7.29 & 5.21 & 0.52 & 9.38 \\
\hline & Net return over FFP (Rs. ha-1) & - & 6160 & 4400 & 440 & 7920 \\
\hline \multirow{6}{*}{$\begin{array}{c}\text { Chickpea } \\
\text { (27) }\end{array}$} & Lowest yield $\left(\mathrm{kg} \mathrm{ha}^{-1}\right)$ & 1437 & 1566 & 1498 & 1466 & 1677 \\
\hline & Highest yield ( $\left.\mathrm{kg} \mathrm{ha}^{-1}\right)$ & 2500 & 2700 & 2650 & 2600 & 2650 \\
\hline & Mean yield $\left(\mathrm{kg} \mathrm{ha}^{-1}\right)$ & 1969 & 2133 & 2074 & 2033 & 2164 \\
\hline & Response over FFP $\left(\mathrm{kg} \mathrm{ha}^{-1}\right)$ & - & 165 & 106 & 65 & 195 \\
\hline & Per cent increase over FFP & - & 8.36 & 5.36 & 3.28 & 9.91 \\
\hline & Net return over FFP (Rs. ha-1) & - & 8019.38 & 5143.13 & 3144.38 & 9506.25 \\
\hline \multirow{6}{*}{ Urdbean (3) } & Lowest yield $\left(\mathrm{kg} \mathrm{ha}^{-1}\right)$ & 1650 & 1850 & 1925 & 1750 & 1975 \\
\hline & Highest yield $\left(\mathrm{kg} \mathrm{ha}^{-1}\right)$ & 1700 & 1850 & 2000 & 1800 & 2150 \\
\hline & Mean yield $\left(\mathrm{kg} \mathrm{ha}^{-1}\right)$ & 1675 & 1850 & 1963 & 1775 & 2063 \\
\hline & Response over FFP $\left(\mathrm{kg} \mathrm{ha}^{-1}\right)$ & - & 175 & 288 & 100 & 388 \\
\hline & Per cent increase over FFP & - & 10.45 & 17.16 & 5.97 & 23.13 \\
\hline & Net return over FFP (Rs. ha $\left.{ }^{-1}\right)$ & - & 9975 & 16387.50 & 5700 & 22087.50 \\
\hline \multirow{6}{*}{ Mustard (70) } & Lowest yield $\left(\mathrm{kg} \mathrm{ha}^{-1}\right)$ & 1100 & 1200 & 1170 & 1120 & 1180 \\
\hline & Highest yield $\left(\mathrm{kg} \mathrm{ha}^{-1}\right)$ & 4200 & 4300 & 4500 & 4200 & 4600 \\
\hline & Mean yield $\left(\mathrm{kg} \mathrm{ha}^{-1}\right)$ & 2650 & 2750 & 2835 & 2660 & 2890 \\
\hline & Response over FFP $\left(\mathrm{kg} \mathrm{ha}^{-1}\right)$ & & 100 & 185 & 10 & 240 \\
\hline & Per cent increase over FFP & - & 3.77 & 6.98 & 0.38 & 9.06 \\
\hline & Net return over FFP (Rs. ha ${ }^{-1}$ ) & - & 4425 & 8186.25 & 442.50 & 10620 \\
\hline \multirow{6}{*}{ Isabgol (3) } & Lowest yield $\left(\mathrm{kg} \mathrm{ha}^{-1}\right)$ & 1000 & 1040 & 1050 & 1030 & 1065 \\
\hline & Highest yield $\left(\mathrm{kg} \mathrm{ha}^{-1}\right)$ & 1120 & 1165 & 1140 & 1130 & 1195 \\
\hline & Mean yield $\left(\mathrm{kg} \mathrm{ha}^{-1}\right)$ & 1060 & 1102.5 & 1095 & 1080 & 1130 \\
\hline & Response over FFP $\left(\mathrm{kg} \mathrm{ha}^{-1}\right)$ & - & 42.5 & 35 & 20 & 70 \\
\hline & Per cent increase over FFP & - & 4.01 & 3.3 & 1.89 & 6.6 \\
\hline & Net return over FFP (Rs. ha ${ }^{-1}$ ) & - & 4186.25 & 3447.50 & 1970 & 6895 \\
\hline \multirow{6}{*}{ Rose (4) } & Lowest yield $\left(\mathrm{kg} \mathrm{ha}^{-1}\right)$ & 27000 & 29000 & 29000 & 28750 & 30500 \\
\hline & Highest yield ( $\left.\mathrm{kg} \mathrm{ha}^{-1}\right)$ & 30000 & 32500 & 32500 & 33000 & 35000 \\
\hline & Mean yield $\left(\mathrm{kg} \mathrm{ha}^{-1}\right)$ & 28500 & 30750 & 30750 & 30875 & 32750 \\
\hline & Response over FFP $\left(\mathrm{kg} \mathrm{ha}^{-1}\right)$ & 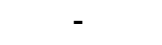 & 2250 & 2250 & 2375 & 4250 \\
\hline & Per cent increase over FFP & - & 7.89 & 7.89 & 8.33 & 14.91 \\
\hline & Net return over FFP (Rs. ha $\left.{ }^{-1}\right)$ & - & 67500 & 67500 & 71250 & 127500 \\
\hline
\end{tabular}

The grain yield under T5 (FFP- $50 \% \mathrm{~N})+$ one spray of each of Nano N, $\mathrm{Zn}, \mathrm{Cu}$ ) was the highest $\left(4628 \mathrm{~kg} \mathrm{ha}^{-1}\right)$ with additional increase of
$297.5 \mathrm{~kg} \mathrm{ha}^{-1}$ over FFP and per cent increase of 6.87. The economic return over FFP was also highest with $\mathrm{T}_{5}$ (Rs. $5726.88 \mathrm{ha}^{-1}$ ) and second in 
order was $\mathrm{T}_{2}$ (FFP-50\% $\mathrm{N}+2$ Spray of Nano $\mathrm{N}$ ). As compared to FFP, the economic return with $\mathrm{T}_{3}(\mathrm{FFP}+2$ Spray of Nano $\mathrm{Zn})$ and $\mathrm{T}_{4}(\mathrm{FFP}+2$
Spray of Nano Cu) were Rs. 3080 and 2791 ha $^{-1}$ respectively.
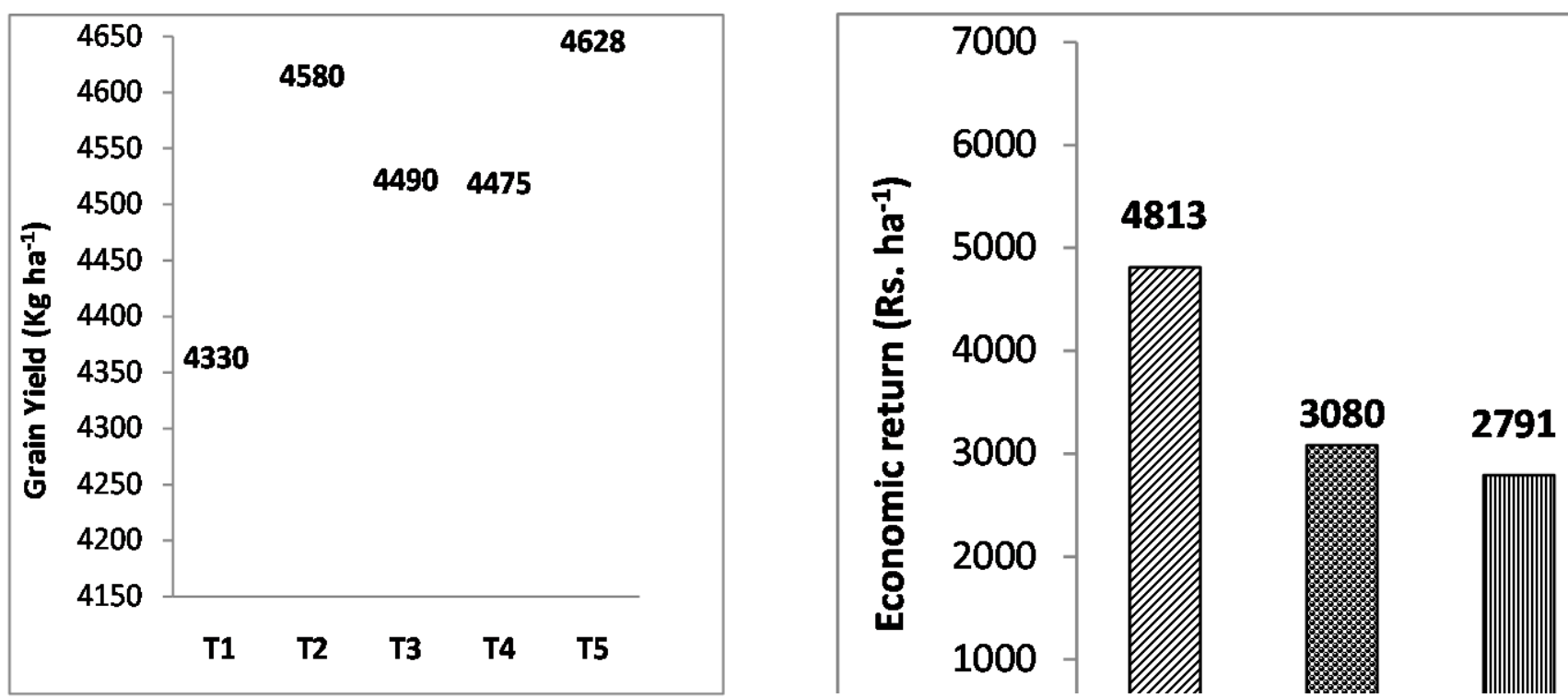

Fig 1: Mean effect of IFFCO Nanofertilizers on grain yield of wheat and economic returns (No. of trials -480 )

\section{Barley (Hordeum vulgare)}

The lowest yields of barley ranged from 3200 and $3380 \mathrm{~kg} \mathrm{ha}^{-1}$ while the highest yield varied between 5260 and $5900 \mathrm{~kg}^{-1}$ under different treatments being highest with $T_{5}$ and the lowest with FFP. The mean yields were in the range of 4230 to $4625 \mathrm{~kg} \mathrm{ha}^{-1}$. The yield

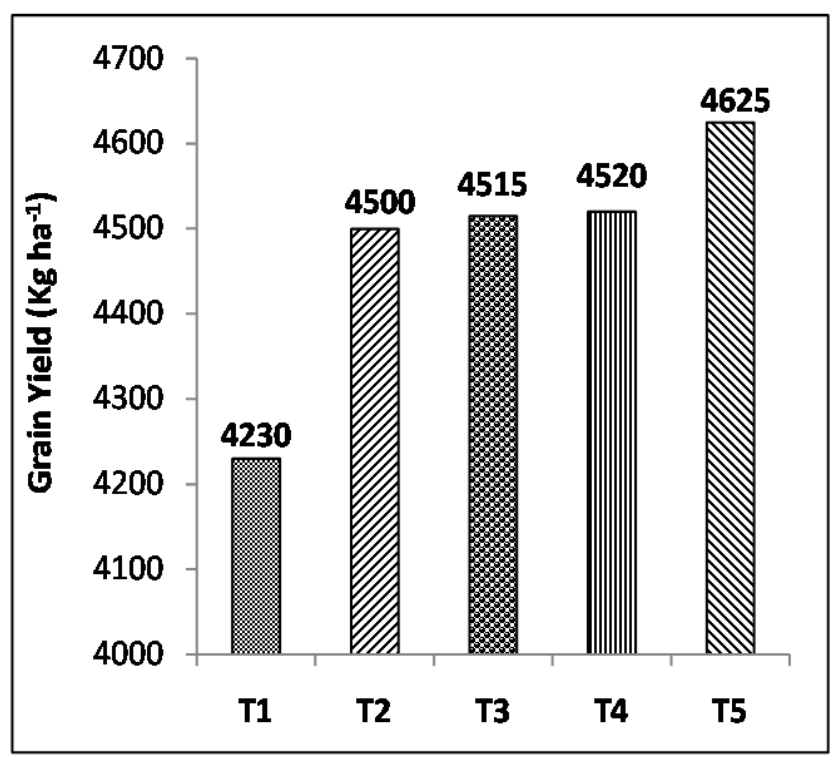

under $T_{5}$ was the highest (4625 $\mathrm{kg} \mathrm{ha}^{-1}$ ) with additional yield of $395 \mathrm{~kg} \mathrm{ha}^{-1}$ over FFP and per cent increase of 9.34. The economic return over FFP was also highest with $T_{5}$ (Rs. 6023.75 ha $^{-1}$ ) followed by $\mathrm{T}_{4}$ (Rs. 4422.50), $\mathrm{T}_{3}$ (FFP +2 Spray of Nano Zn) (Rs.4346.25) and $\mathrm{T}_{2}$ (FFP-50\% N + 2 Spray of Nano N) (Rs. 4117.50), respectively (Table 2 and Fig. 2).

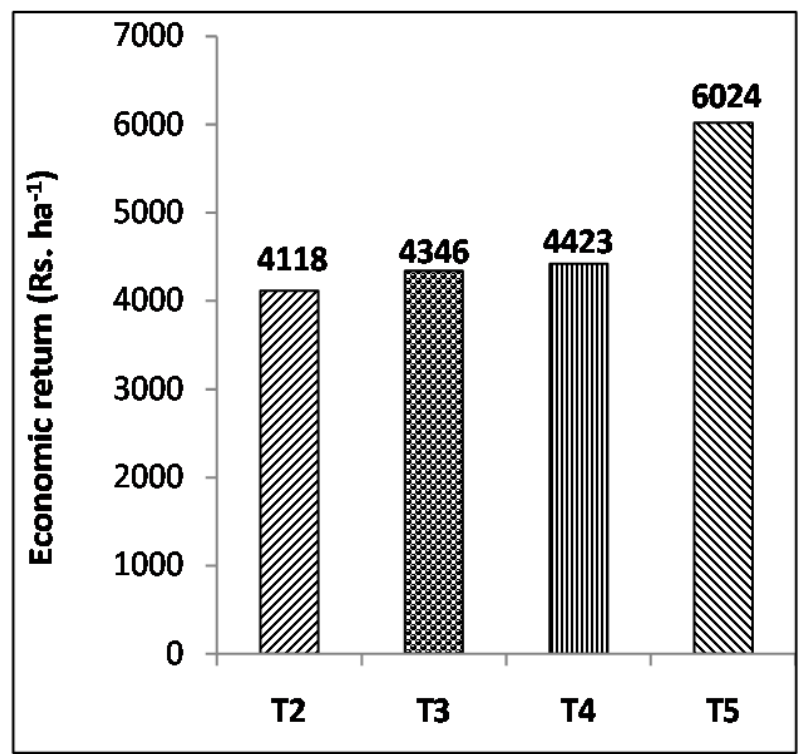

Fig. 2: Mean effect of IFFCO Nanofertilizers on grain yield of Barley and economic returns (No. of trials -9) 


\section{Maize (Zea mays)}

Data presented in Table 2 and Fig. 3 show that the lowest grain yield of maize as influenced by different treatments ranged from 4100 to 4500 and the highest from 5500 to 6000 $\mathrm{kg} \mathrm{ha}^{-1}$. The mean grain yield under different treatments varied between 4800 and $5250 \mathrm{~kg}$ ha
${ }^{1}$ being highest under $T_{5}$ and the lowest under FFP with per cent increase of 9.38. The additional yield under $T_{5}$ over FFP was $450 \mathrm{~kg}$ $\mathrm{ha}^{-1}$. The economic return over FFP was also highest with $T_{5}$ (Rs.7920 ha ${ }^{-1}$ ) followed by $T_{2}$ (Rs.6160 ha- ${ }^{-1}$ ), $\mathrm{T}_{3}$ (Rs.4400 ha ${ }^{-1}$ ), and $\mathrm{T}_{4}$ (Rs. $\left.440 \mathrm{ha}^{-1}\right)$.
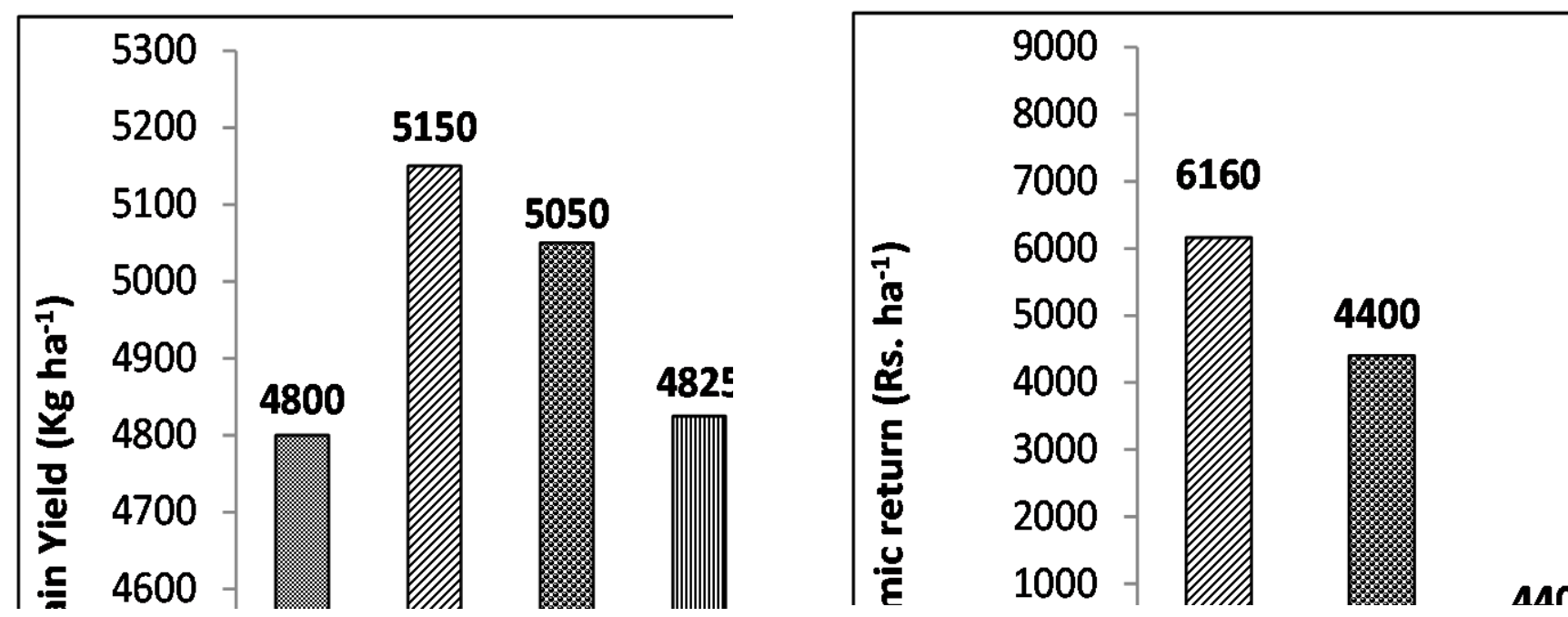

Fig. 3: Mean effect of IFFCO Nanofertilizers on grain yield of maize/ Corn and economic returns (No. of trials-4)

\section{Chickpea (Cicer arietenum)}

Perusal of the data from the field trials of chickpea presented in Table 2 and Fig. 4 shows that the lowest grain yield under different treatments ranged from 1437 to $1677 \mathrm{~kg} \mathrm{ha}^{-1}$ and the highest from 2500 to $\left.2700 \mathrm{~kg} \mathrm{ha}^{-1}\right)$. The grain yield was highest under $T_{5}\left(2164 \mathrm{~kg} \mathrm{ha}^{-1}\right)$ with per cent increase of 9.91and the lowest under FFP (1969 kg ha-1). The next highest yield

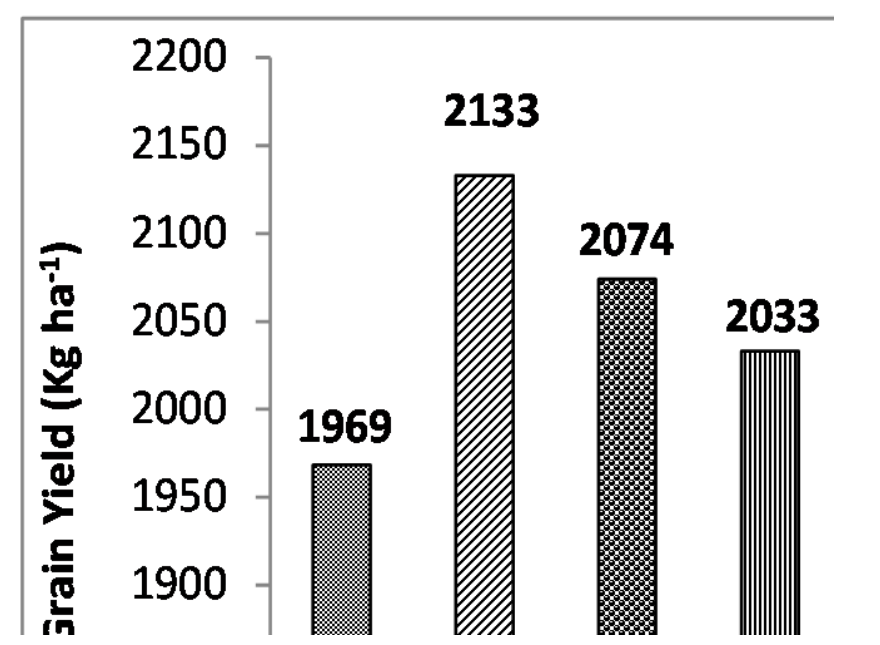

was with $\mathrm{T}_{2}(\mathrm{FFP}-50 \% \mathrm{~N})+2$ Spray of Nano N) $\left(2133 \mathrm{~kg} \mathrm{ha}^{-1}\right.$ with additional yield of $165 \mathrm{~kg} \mathrm{ha}^{-1}$ valuing Rs. $8019.38 \mathrm{ha}^{-1}$ over FFP. The highest yield $\left(2164 \mathrm{~kg} \mathrm{ha}^{-1}\right)$ with additional yield of 195 $\mathrm{kg} \mathrm{ha}^{-1}$ and percent increase to the order of $9.01 \%$ gave economic return to the tune of Rs. 9506 ha $^{-1}$ over FFP. The economic returns with $\mathrm{T}_{2}, \mathrm{~T}_{3}$ and $\mathrm{T}_{4}$ were Rs. 8019, 5143, and 3144 respectively over FFP.

Fig. 4: Mean effect of IFFCO Nanofertilizers on grain yield of Chick Pea/ BangalGram and economic returns (No. of trials-27) 


\section{Urdbean (Vigna mungo)}

Data on grain yield of urdbean and economic returns as influenced by different treatments presented in Table 2 and Fig. 5 show that the lowest grain yield under different treatments ranged from 1650 to $1975 \mathrm{~kg} \mathrm{ha}^{-1}$ with highest yield from 1700 to $2150 \mathrm{~kg} \mathrm{ha}^{-1}$. The mean grain yield ranged from 1675 to $2063 \mathrm{~kg}$ $\mathrm{ha}^{-1}$ being the highest under T5 $\left(2063 \mathrm{~kg}^{-1} \mathrm{ha}\right)$ and the lowest under FFP $\left(1675 \mathrm{~kg} \mathrm{ha}^{-1}\right)$ with per cent increase of 23.13.The additional grain yield under different treatments over FFP varied between 100 to $388 \mathrm{~kg} \mathrm{ha}^{-1}$ being highest under $\mathrm{T}_{5}\left(388 \mathrm{~kg} \mathrm{ha}^{-1}\right)$ followed by $\mathrm{T}_{3}\left(288 \mathrm{~kg} \mathrm{ha}^{-1}\right), \mathrm{T}_{2}$ $\left(175 \mathrm{~kg} \mathrm{ha}^{-1}\right)$ and $\mathrm{T}_{4}\left(100 \mathrm{kgha}^{-1}\right)$. The economic return over FFP was also highest with $\mathrm{T}_{5}$ (Rs. $22087 \mathrm{ha}^{-1}$ ) followed by $\mathrm{T}_{3}$ (Rs. $\left.16387 \mathrm{ha}^{-1}\right), \mathrm{T}_{2}$ (Rs.9975 ha- ${ }^{-1}$ ) and $\mathrm{T}_{4}\left(\right.$ Rs. $5700 \mathrm{ha}^{-1}$ ).
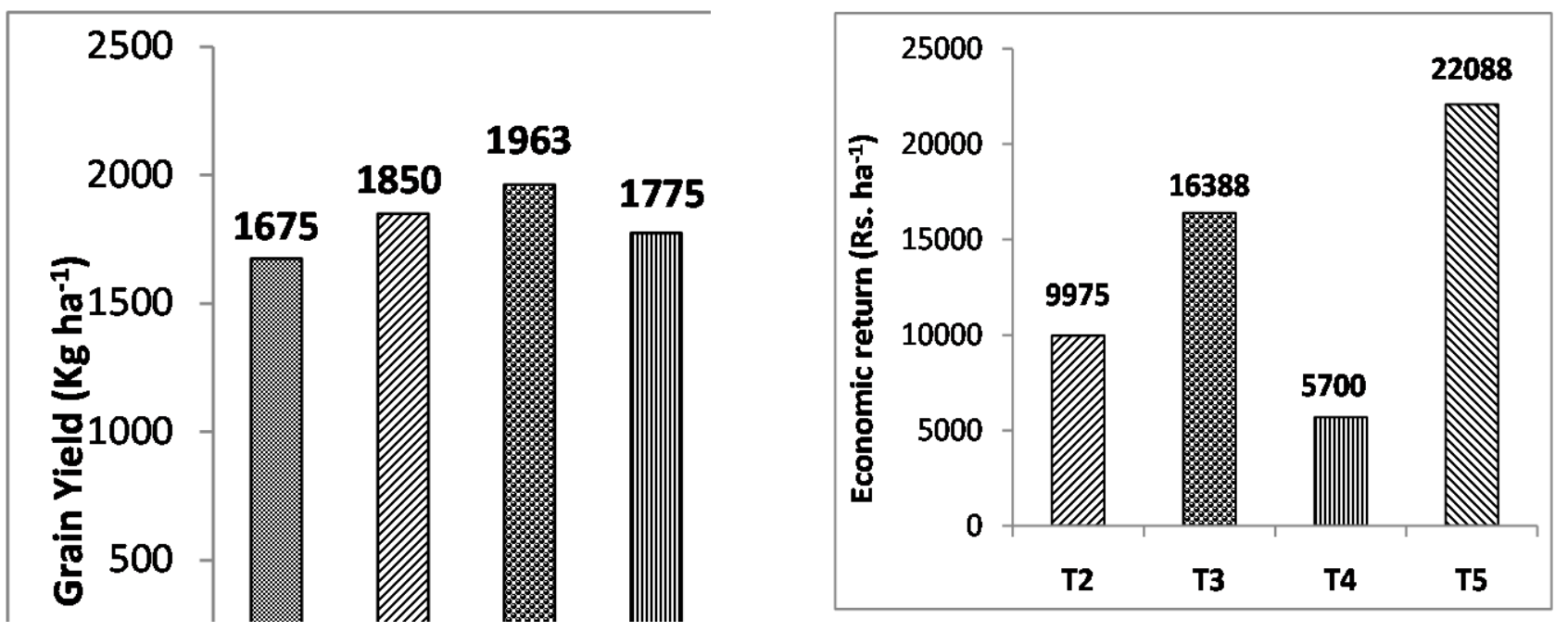

Fig. 5: Mean effect of IFFCO Nano-Fertilizers on grain yield of urdbeanand economic returns (No. of trials-3)

\section{Mustard (Brassica juncea)}

Data on grain yield, additional grain yield and economic returns of mustard as influenced by different treatments presented in Table 2 and Fig. 6show that the lowest yieldsvaried in a very narrow range from 1100 to $1200 \mathrm{~kg} / \mathrm{ha}$ and the highest from 4200 to $4600 \mathrm{~kg} \mathrm{ha}^{-1}$.
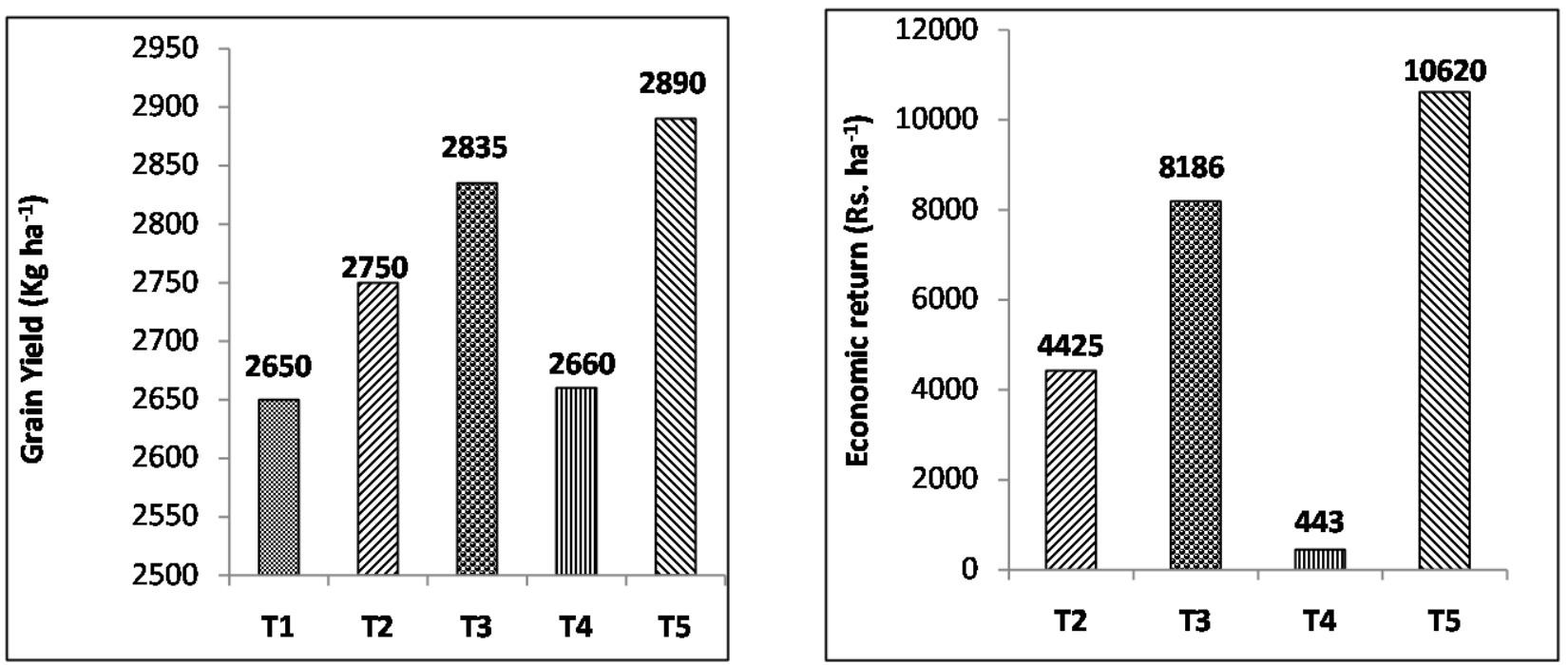

Fig. 6: Mean effect of IFFCO Nanofertilizers on grain yield of mustard and economic returns (No. of trials-70) 
The mean grain yield under different treatments varied between 2650 and $2890 \mathrm{~kg}$ ha ${ }^{1}$ being highest under $T_{5}$ and the lowest under FFP with per cent increase of 9.91. The additional yield under 5 over FFP was $240 \mathrm{~kg}$ ha ${ }^{1}$ followed by $T_{3}\left(185 \mathrm{~kg} \mathrm{ha}^{-1}\right), \mathrm{T}_{2}\left(100 \mathrm{~kg} \mathrm{ha}^{-1}\right)$ and $\mathrm{T}_{4}\left(10 \mathrm{~kg} \mathrm{ha}^{-1}\right)$. The economic return over FFP was also highest with $T_{5}$ (Rs.10620 ha-1) followed by $\mathrm{T}_{3}$ (Rs.8186 ha-1 $), \mathrm{T}_{2}\left(\mathrm{Rs} .4400 \mathrm{ha}^{-1}\right)$, and $\mathrm{T}_{4}$ (Rs. $442 \mathrm{ha}^{-1}$ ).

\section{Isabgol(Plantago ovata)}

Effect of nanofertilsers on grain yield, additional grain yield and economic returns over
FFP have been presented in Table 2 and Fig. 7.The lowest yield of isabgolas influenced by different treatments ranged from 1000 to 1065 $\mathrm{kg} \mathrm{ha}^{-1}$, the highest between 1120 and $1195 \mathrm{~kg}$ $\mathrm{ha}^{-1}$ and the mean yield in the range of 1060 to $1130 \mathrm{~kg} \mathrm{ha}^{-1}$. The mean yield was highest under $\mathrm{T}_{5}\left(1130 \mathrm{~kg} \mathrm{ha}^{-1}\right)$ followed by $\mathrm{T}_{2}\left(1103 \mathrm{~kg} \mathrm{ha}^{-1}\right)$, $\mathrm{T}_{3}\left(1095 \mathrm{~kg} \mathrm{ha}^{-1}\right)$ and $\mathrm{T}_{4}\left(1080 \mathrm{~kg} \mathrm{ha}^{-1}\right)$ and $\mathrm{T}_{1}$ $\left(1060 \mathrm{~kg} \mathrm{ha}^{-1}\right)$. The additional yield over FFP followed the same trend being $70,42,35$ and 20 $\mathrm{kg} \mathrm{ha}^{-1}$ under $\mathrm{T}_{5}, \mathrm{~T}_{2}, \mathrm{~T}_{3}$ and $\mathrm{T}_{4}$, respectively. The economic return over FFP was also highest with $\mathrm{T}_{5}\left(\mathrm{Rs} .6895 \mathrm{ha}^{-1}\right)$, followed by $\mathrm{T}_{2}\left(\mathrm{Rs} .4186 \mathrm{ha}^{-1}\right)$, $\mathrm{T}_{3}\left(\right.$ Rs. $\left.3448 \mathrm{ha}^{-1}\right)$ and $\mathrm{T}_{4}\left(\right.$ Rs. $\left.1970 \mathrm{ha}^{-1}\right)$.
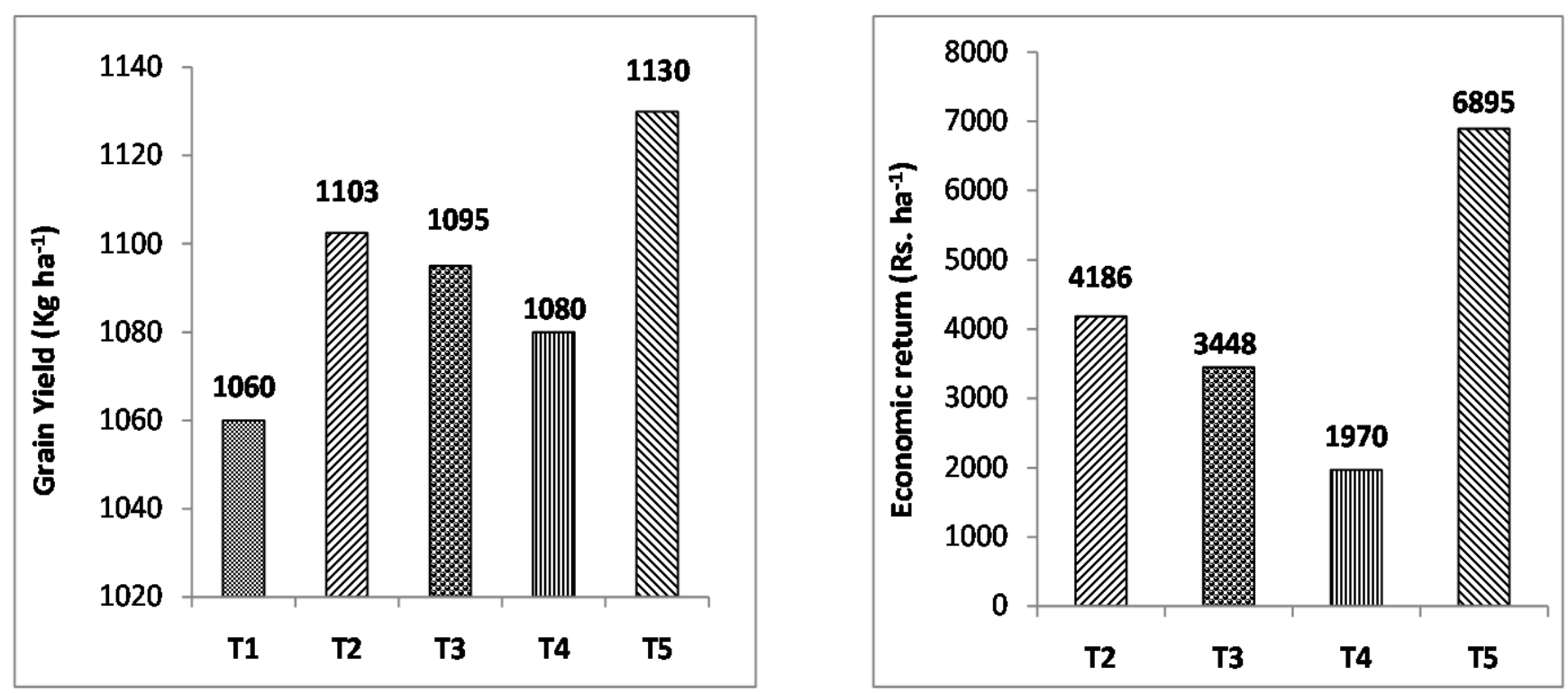

Fig. 7:Mean effect of IFFCO Nanofertilizers on the yield of Isabgol and economic returns (No. of trials -3 )

\section{Rose (Rosa damascene)}

Perusal of the data from the field trials of roses (Table 2 and Fig.8) showed that the lowest flower yields as influenced by different treatments varied in the range of 27000 to 30500 $\mathrm{kg} \mathrm{ha}^{-1}$, the highest between 30000 and 35000 $\mathrm{kg} \mathrm{ha}^{-1}$ and the mean yield in the range of 28500 to $32750 \mathrm{~kg} \mathrm{ha}^{-1}$. The flower yield was highest under $T_{5}\left(32750 \mathrm{~kg} \mathrm{ha}^{-1}\right)$ with per cent increase of 14.91 and the lowest under FFP $(28500 \mathrm{~kg}$ ha $\left.{ }^{1}\right)$. The next highest yield $\left(30875 \mathrm{~kg} \mathrm{ha}^{-1}\right)$ was with $\mathrm{T}_{4}(\mathrm{FFP}+2$ Spray of Nano $\mathrm{Cu}$ ) followed by $\mathrm{T}_{2}$ and $\mathrm{T}_{3}\left(30750 \mathrm{~kg} \mathrm{ha}^{-1}\right)$ and the lowest under FFP (28500 kg ha-1) with additional yield of 4250 $\mathrm{kg} \mathrm{ha}{ }^{-1}$ over FFP under $T_{5}, 2375 \mathrm{~kg} \mathrm{ha}^{-1}$ under $\mathrm{T}_{4}$ and $2250 \mathrm{~kg} \mathrm{ha}^{-1}$ under $\mathrm{T}_{2}$ and $\mathrm{T}_{3}$ and valuing
Rs. 127500 ha $^{-1}$ under $T_{5}$, Rs. 71250 under $\mathrm{T}_{4}$, and Rs. 67500 under $T_{2}$ and $T_{3}$ over FFP.

Conventional fertilizers offer nutrients in chemical forms that are not fully accessible to plants. Additionally, the inversion of these chemicals to insoluble form in soil is the reason for the very low utilization of most of the macro and micronutrients. Heavy use of nitrogen $(\mathrm{N})$ and phosphorus $(\mathrm{P})$ fertilizers has become the major anthropogenic factors resulting in worldwide eutrophication problems in freshwater bodies and coastal ecosystems (Conley et al. 2009). In the perspective of sustainable agriculture, the application of modern nanotechnology in agriculture is considered asone of the important approaches to enhance crop production considerably and feed the 
world's fast growing population (Lal 2008). Important benefits of nanofertilizers over conventional chemical fertilizers rely on their (i) nutrient delivery systems as they regulate the availability of nutrients in crops through slow/control release mechanisms. Such a slow delivery of nutrients is associated with the covering or cementing of nutrients with nanomaterials. By taking advantage of this slow nutrient delivery, farmers can increase their crop growth because of consistently long-term delivery of nutrients to plants. For example, nutrients can be released over $40-50$ days in a slow release fashion rather than the 4-10 days by the conventional fertilizers, (ii) In addition, nanofertilizers are required in small amount which reduce the cost of transportation and field application, (iii) An additional major advantage is over accumulation of salt in soil can be minimized as it required in small amount, (iv) Another advantage for using nanofertilizers is that they can be synthesized according to the nutrient requirements of planned crops. In this regard, biosensors can be attached to a new innovative fertilizer that controls the delivery of the nutrients according to soil nutrient status, growth period of a crop or environmental conditions, (v) The miniature size, high specific surface area and high reactivity of nanofertilzers increase the bioavailability of nutrients and (vi) Providing balanced nutrition, nanofertilizers facilitate the crop plants to fight various biotic and abiotic stresses. It is reported in several crops that use of nanofertlizers and nanomaterials enhanced the growth and yield in several crops relative to plant treated with conventional fertilizers. Therefore, a paradigm shift from the traditional ways of crop production to technologies that could increase agricultural productivities with required nutrients, cost effective and efficient resource use that guarantees nutrient security, uplifts the value of production, boosts farmers' economy, delivers agri-value chain and supports pollution free environment is, therefore, the need of the day (Subramanian and Tarafdar 2011). The engineered nanoparticles (ENPs) are able to enter into plants cells and leaves, and can also transport DNA and chemicals into plant cells (Galbraith, 2007, Torneyet al. 2007). The purpose of using nanomaterials (NMs) in the field of agriculture is to improve the efficiency and sustainability of agricultural practices by putting less input and generating less waste than conventional products and approaches.
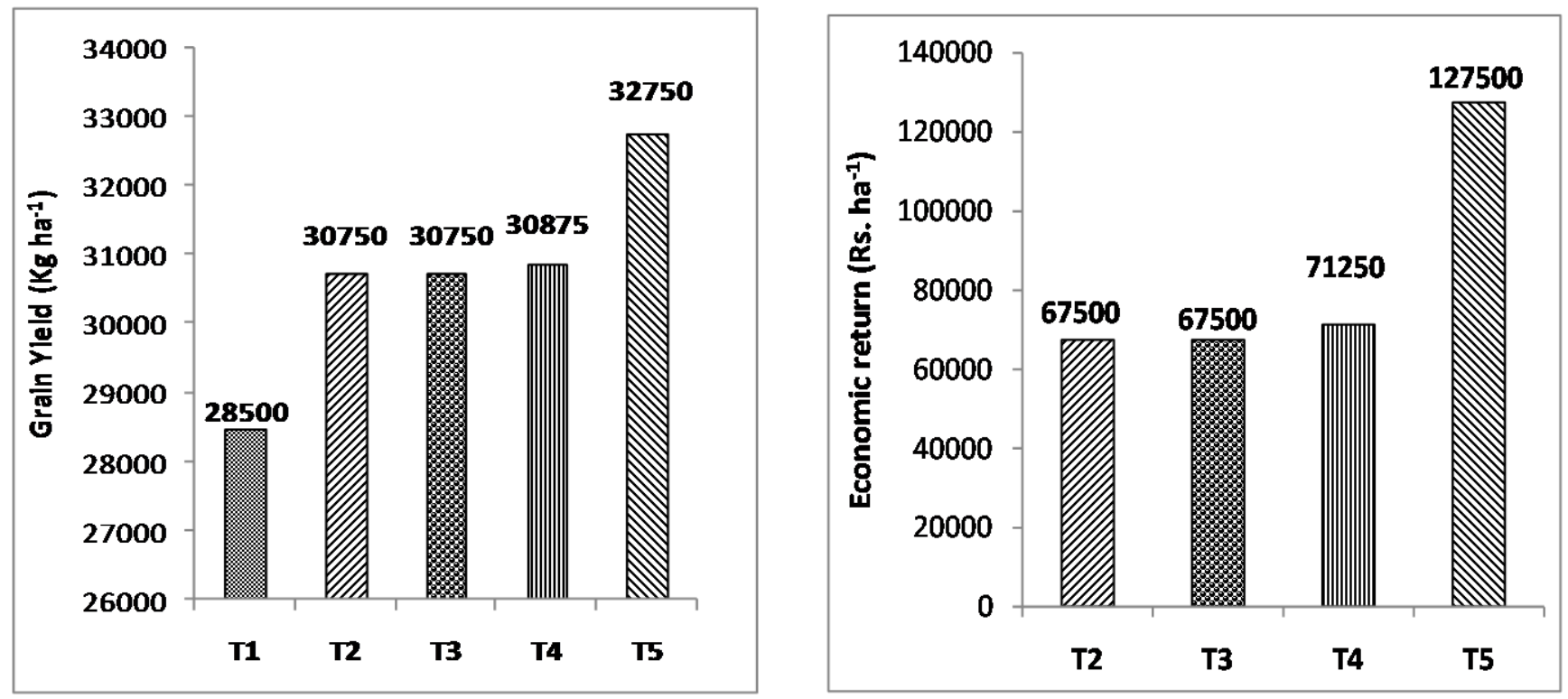

Fig. 8: Mean effect of IFFCO Nanofertilizers on the yield of Rose and economic returns (No. of trials - 4)

Plant fertilizers can be applied through the soil (for uptake by plant roots), through foliar spray (for uptake through leaves) (O'Neill et al. 2014) or both ways together (Yan et al. 2018). In this connection, carrier delivery systems of nanofertilizers can synchronize their 
release with their uptake by crops thus preventing undesirable loss of nutrients to soil (De Rosaet al. 2010). Some characteristics of nanoparticles, including the large specific surface area, unique magnetic/optical properties, electronic states, and catalytic re-activity confer nanoparticles a better reactivity than the equivalent bulk materials (Agrawal and Rathore, 2014). The actual application of delivery system for nanofertilizers came rather recently in agriculture (Roco 2011; Scott and Chen 2013). Nanofertilizers are aimed to make nutrients more available, consequently increasing nutrient use efficiency (Suppan, 2013). With nanofertilizer, there is slow release of the nutrients, which minimizes leaching of the nutrients among other interesting properties. The use of nanofertilizers is the most important application of nanotechnology in agriculture so far (Agrawal and Rathore, 2014). Regarding N fertilizers, the application of nanotechnology can provide fertilizers that release $\mathrm{N}$ when crops need it, eventually leading to increases in $\mathrm{N}$ efficiency through decreases in $\mathrm{N}$ leaching and emissions and long-term incorporation by soil microorganisms (Naderi and Danesh-Shahraki, 2013; Suman et al., 2010).Nanofertilizers due to their characteristic features have great role in sustainable agriculture (El- Ramady 2014). Nanofertilizers or nano-encapsulated nutrients have properties effectively to release nutrients and chemical fertilizers on demand that regulate plant growth and enhance target activity (Nair et al. 2010). Nanoscale science and nanotechnology have the potential to transform the agriculture and food systems (Norman and Hongda 2013).

According to recent research works, nanofertilizers or nano-encapsulated nutrients have properties effectively to release nutrients and chemical fertilizers on demand that regulate plant growth and enhance target activity (Nair et al. 2010). Nanotechnology has the possibility to revolutionize agricultural systems (Manjunathaet al. 2016) enabling slow and controlled release of nutrient for the plants benefit, and ultimately increasing the amount of crop production with low environmental impact (Scott and Chen 2013). Nanotechnology seems to be the alternative that could revolutionize this field of agriculture which has the potential to increase food quality, global food production, plant protection, detection of plant and animal diseases, monitoring of plant growth and reduce waste for "sustainable amplification" (Prasad et al. 2014, Biswalet al. 2012, Ditta 2012, Sonkaria 2012). It has immense potentials in agricultural uprising, high reactivity, better bioavailability, bioactivity and the surface effects of NPs (Gutiérrez et al. 2011). Nanofertilizers or nanoencapsulated nutrients have properties effectively to release nutrients on demand that regulate plant growth and enhance target activity (Rosa et al. 2010, Nair et al. 2010). Urea modified hydroxyapatite nanoparticleencapsulated Gliricidiasepiumnanocomposite exhibited a slow and sustained release of nitrogen over time at 3 different $\mathrm{pH}$ values (Kottegoda et al, 2011). Manikandan and Subramanian (2014) reported that nanoporous zeolite used on $\mathrm{N}$ fertilizer might be used as alternate strategy to enhance the effectiveness of $\mathrm{N}$ used in crop production system. Soil amended with metallic $\mathrm{Cu}$ NPs significantly increased 15 day lettuce seedling growth by $40 \%$ and 91\%, respectively (Shah and Belozerova 2009). Some studies focused on the characteristics of NPs also revealed that NPs can enter plant cells and transport DNA and chemicals inside the cell (Ambrogioet al. 2013, Ghafariyanet al. 2013, Torney et al. 2007). These studies provide a platform on which we can assume that NPs can also deliver nutrients to the plants as fertilizers. Moreover, nanofertilezers have great impact on the soil as nanofertilizers can reduce the toxicity of the soil and decrease the frequency of fertilizer application (Naderi and Danesh-Shahraki 2013). DeRosaet al. (2010) reported that in nanofertilizers, nutrients can be encapsulated by NMs, coated with a thin protective film or delivered as emulsions or NPs. Nano and subnano composites control the release of nutrients from the fertilizer capsule (Liu et al. 2006). Nanoscale science and nanotechnology have the potential to transform the agriculture and food systems (Norman and Hongda, 2013). In previous studies, urea-loaded zeolite chips (Millan et al., 2008) and nanocomposites containing N (Jinghua, 2004) have been used to induce a slow $\mathrm{N}$ release and increase plant $\mathrm{N}$ uptake. Other materials being used for the same purpose include nutrient sources coated with thin polymer films and nutrients encapsulated inside nanoporous materials (Rai et al., 2012). 
In conclusion, nanotechnology designing ultra-small particles is now emerging as a promising way to promote plant growth and development. Nanofertilisers are expected to conserve natural mineral reserves and energy (as making fertilizer is very energy-intensive), enhance nutrient use efficiency, reduce water contamination and protect environment arresting nutrient losses and enhance crop yields. It also can enhance plants' nutritional values. Most of the researches conducted at global level on nanofertilizerssuggest that these materials could help solve the world's most pressing resource problems at the food-energy-water nexus. Apparently, nanotechnology have greater role in

\section{REFERENCES}

Agrawal, S. and Rathore, P. (2014) Nanotechnology pros and cons to agriculture: A review. International Journal of Current Microbiology and Applied Sciences 3:43-55.

Ambrogio, M. W., Frasconi, M., Yilmaz, M. D. and Chen X. (2013) New methods for improved characterization of silica nanoparticlebased drug delivery systems, Langmuir 29: 15386-15393.

Biswal, S. K., Nayak, A. K., Parida, U. K., and Nayak, P. L. (2012) Applications of nanotechnology in agriculture and food sciences. International Journal of Science Innovations and Discoveries 2(1): 21-36.

Brennan, B. (2012) Nanobiotechnology in agriculture.Strategic business insights. Menlo Park, CA, USA, Available from: http://www.strategicbusinessinsights.com /about/featured/2012/2012-anobioagriculture.shtml.

Conley, D. J., Paerl, H. W., Howarth R. W., Boesch, D. F., and Seitzinger, S. P. (2009) Ecology controlling eutrophication: nitrogen and phosphorus. Science 323: 1014-1015.

De Rosa, G., Lopez-Moreno, M. L., De Haro, D., Botez, C. E., Peralta-Videa, J. R. and Gardea-Torredey (2013) Effects of ZnO nanoparticles in alfalfa, tomato, and cucumber at the germination stage: root development and x-ray absorption spectroscopy studies. Pure applied Chemistry 85 (12): 2161-2174. crop production with environmental safety, ecological sustainability and economic stability.

\section{ACKNOWLEDGEMENT}

We are highly grateful to Dr. U. S. Awasthi, Managing Director, IFFCO for his keen interest, constant supervision, wholehearted support and praiseworthy guidance to initiate and successfully complete this investigation. We sincerely extend our thanks to IFFCO Field Officers for religiously conducting these on farm trials and collecting data successfully, especially during COVID-19 lock-down period safely observing full precaution.

De Rosa, M. C., Monreal, C., Schnitzer, M., Walsh, R. and Sultan, Y. (2010) Nanotechnology in fertilizers. Nature Nanotechnology 5:91. doi: 10.1038/nnano. 2010.2.

Ditta, A. (2012) How helpful is nanotechnology in agriculture? Advances in Natural Sciences, Nanoscience and Nanotechnology 3 (3): 033002.

El-Ramady, H. R. (2014) Integrated Nutrient Management and Postharvest of Crops. Sustainable Agriculture Reviews, (E.Litchfouse, Ed.) 13: 163-274.

Galbraith, D. W. (2007) Nanobiotechnology: silica breaks through in plants. Nature Nanotechnology 2(5): 272-273.

Gardea-Torresdey, J. L., Rico, C. M., and White, J. C. (2014) Trophic transfer, transformation, and impact of engineered nanomaterials in terrestrial environments. Environmental Science and Technology 48: 2526-2540.

Ghafariyan, M. H., Malakouti M. J., Dadpour M. R., Stroeve, P. and Mahmoudi, M. (2013) Effects of magnetite nanoparticles on soybean chlorophyll. Environmental Science and Technology 47: 1064510652.

Gutiérrez, F. J., Mussons,M. L., Gatón, P. and Rojo, R. (2011). Nanotechnology and Food Industry.Scientific, Health and Social Aspects of the Food Industry.Book Chapter in Tech. Croatia. https://api.intechopen.com/chapter/pdfpreview/27382. 
Iran Nanotechnology Initiative Council (INIC) (2009) First nanoorganic ion chelated fertilizer invented in Iran (webpage on the internet) Tehran: Iran: Iran Nanotechnology nitiative Council http://www.iranreview.org/content/docum ents/ Iranians Researchers Produce Nano Organic Fertilizer.

Jinghua, G. (2004). Synchrotron radiation, soft $X$-ray spectroscopy and nanomaterials. IntlernationalJournal of Nanotechnology 1:193-225.

Kottegoda, N., Munaweera, I. Madusanka, N. and Karunaratne, V. (2011) A green slow-release fertilizer composition based on urea modified hydroxyl apatite nanoparticles encapsulated wood.Current Science 101(1): 73-78.

Lal, R. (2008) Promise and limitations of soils to minimize climate change. Journal of Soiland Water Conservation 63:113A118 A.

Liu, X., Feng, Z., Zhang S., Zhang, J., Xiao, Q. and Wang, Y. (2006) Preparation and testing of cementing nano-subnano composites of slow or controlled release of fertilizers. Scientific AgricultureSinica 39: 1598-1604.

Manikandan, A. and Subramanian, K. S. (2014) Fabrication and characterisation of nanoporous zeolite based $\mathrm{N}$ fertilizer, African Journal of Agricultural Research 9 (2) 276-284.

Manjunatha, S.B.; Biradar, D.P. and Aladakatti, Y.R. (2016) Nanotechnology and its applications in agriculture: A review. Journal of Farm Sciences 29: 1-3.

Millan, G., Agosto F. and Vazquez, M. (2008). Use of clinoptilolite as a carrier for nitrogen fertilizers in soils of the Pampean regions of Argentina. Ciencia Investigation Agraria 35 : 293-302.

Naderi, M. R. and Danesh-Shahraki, A. (2013). Nanofertilizers and their roles in sustainable agriculture. International Journal of Agriculture and Crop Sciences 5: 2229-2232.

Naderi, M. R. andDaneshShahraki, A. (2013) Nanofertilizers and their roles in sustainable agriculture. International Journal of Agriculture and Crop Sciences 5 (19): 2229-2232.

Nair, R., Varghese, S. H., Nair, B. G., Maekawa, T., Yoshida, Y. and Kumar, D.S. (2010)
Nanoparticulate material delivery to plants. Plant Science 179: 154-163.

Norman, S. and Hongda, C. (2013) IB IN DEPTH Special Section on Nanobiotechnology, Part 2. Industrial Biotechnology 9: 17-18.

O' Neill, A. Sen Gupta, B. and Phillips, D. H. (2014) Distribution of arsenic and risk assessment of activities on a golf course fertilized with arsenic- containing Ascophyllumnodosum seaweed. Science of Total Environment 483: 252-259

Panwar, J. Jain, N. Bhargav, A. Akhtar, M. S. and Yun, Y. S. (2012) Positive effect of zinc oxide nanoparticles on tomato plants: a step towards developing "Nano-fertilizers". In: Proceedingsof $3^{\text {rd }}$ international conference on environmental research and technology (ICERT), May 30- June 1, 2012, Penang, Malaysia. Pp 348-352.

Prasad, R., Kumar, V. and Prasad, K. S. (2014) Nanotechnology in sustainable agriculture: present concerns and future aspects. African Journal of Biotechnology 6: 13705-713.

Rai, V., Acharya, S.andDey.N. (2012) Implications of nanobiosensors in agriculture. Journal of Biomaterials and Nanobiotechnology 3: 315-324.

Roco, M.C. (2011) The long view of nanotechnology development: the National Nanotechnology Initiative at 10 years. Journal of Nanoparticles Research 13 (2): 427-445.

Rosa De, Monreal, M. C., Schnitzer, C., Walsh, M.R. and Sultan, Y. (2010) Nanotechnology fertilizers. NatureNanotechnology 5: 91.

Saigusa, M. (2000) Broadcast application versus band application of polyolefin-coated fertilizer on greenpeppers grown on Andesol. Journal of Plant Nutrition 23: 1485-1493.

Scott, N. and Chen, H. (2013) Nanoscale science and engineering for agriculture and food systems. Industrial Biotechnology 9:17-18.

Shah, V.andBelozerova, I. (2009) Influence of metal nanoparticles on the soil microbial community and germination of lettuce seeds, Water, Air and Soil Pollution 197: 143-148. 
Solanki, P., Bhargava, A., Chhipa, H., Jain, N., and Panwar, J. (2015) Nanofertilizers and their smart delivery systems. In: Rai, M, Ribeiro, C., Mattaso, L. and Duran, N. (eds) Nanotechnologies in food and agriculture. Springer, Switzerland, pp 81101.

Sonkaria, S.,Ahn, S.H. and Khare, V. (2011) Nanotechnology and its impact on food and nutrition: a review. Recent Patents on Food Nutrition and Agriculture 4(1): 8-18.

Subramanian, K.S., Manikandan, A., Thirunavukkarasu, M. and Rahale, C.S.(2015) Nanofertilizers for balanced crop nutrition. In: Rai, M, Ribeiro, C., Mattaso, L. and Duran, N. (eds) Nanotechnologies in food and agriculture. Springer, Switzerland, pp 6980

Subramanian, K.S. and Tarafdar, J.C. (2011) Prospects of nanotechnology in Indian farming.Indian Journal of Agricultural Sciences 81: 887-893.

Sugunan, A. and Dutta, J. (2008) Pollution treatment, remediation and sensing. In: Harald, K. (ed) Nanotechnology, vol. 3, Wiley-VCH, Weinheim, pp 125-143.

Suman, P.R., Jain, V.K. and Varma, A. 2010. Role of nanomaterials in symbiotic fungus growth enhancement. Currrent Science 99: 1189-1191.
Suppan, S. (2013) Nanomaterials in soil: Our future food chain. The institute of agriculture and trade policy, Minneapolis, MN, USA.

Torney F, Trewyn, B.G. Lin V.S. and Wang, K. (2007) Mesoporous silica nanoparticles deliver DNA and chemicals into plants. Nature Nanotechnology 2 (5): 295-300.

Trenkel, M.E. (2010) Slow and controlledrelease and stabilized fertilizers: an option for enhancing nutrient use efficiency in agriculture. International Fertilizer Industry Association, Paris, France, pp 1-162.

United Nation Department of Economic and Social Affairs (2015) World Population Projected to Reach 9.6 Billion by 2050. United Nation Department of Economic and Social Affairs: New York, USA,

Yan, X.L., Dai, T.F., and Jia, L.M. (2018) Evaluation of the cumulative effect of drip irrigation and fertigation on productivity in a poplar plantation. Annals of Forest Science 75 (1): 5. doi: 10.1007/s13595017-0682-6.

Zheng, L., Hong, F.S., Lu, S.P. and Liu, C. (2005) Effect of nano-TiO2 on strength of naturally and growth aged seeds of spinach. Biological Trace Element Research 104: 83-91. 